\title{
Weathering and post-depositional evolution of a Neoarchean paleosol
}

MichaEl G. BABECHUK ${ }^{1 *}$, Eva E. STÜEKEN ${ }^{2}$, GABRIEL P. SINDOL ${ }^{1}$, CAROLINA ROSCA $^{3}$, RONNY SCHOENBERG ${ }^{3}$

${ }^{1}$ Dept. of Earth Sciences, Memorial University of

Newfoundland, Canada (*mbabechuk@mun.ca)

${ }^{2}$ Sch. Earth \& Env. Sciences, University of St Andrews, UK

${ }^{2}$ Dept. of Geosciences, University of Tübingen, Germany

The trace and major element geochemistry of ca. $2.76 \mathrm{Ga}$ basalt-hosted paleosol horizons (the Mt. Roe paleosols) in the Fortescue Group, NW Australia is widely cited as evidence for very low atmospheric $\mathrm{O}_{2}$ in the Neoarchean [e.g. 1]. These conclusions were supported by the trace metal and $\mathrm{Mo}-\mathrm{Cr}$ stable isotope geochemistry of overlying black shales [2]. However, a subsequent study on the Mt. Roe paleosols revealed evidence for cryptic oxidative $\mathrm{Cr}-\mathrm{V}$ cycling that survived hydrothermal overprinting [3]. This study revisits these paleosols via samples from the Archean Biosphere Drilling Project (ABDP) \#6 drillcore that cover 2 progressions through parental basalt, altered basalt, and overlying shale. Multiple major and trace element proxies and C-N systematics are applied to further address the parental basalt petrogenesis and preserved paleo-redox and postdepositional signatures.

Immobile elements that were residually enriched during alteration (e.g. Al, Ti, Nb, Ta, Zr, Hf, Th) have highly consistent ratios and allow their use in mass balance and petrogenetic analysis. Consistent with the earliest studies of the paleosol, there are negligible $\mathrm{Ce}$ anomalies and no evidence for significant $\mathrm{U}, \mathrm{Cr}$ or $\mathrm{V}$ mobilization across the full alteration progression. Several mobile elements (e.g. $\mathrm{Rb}$, $\mathrm{Cs}, \mathrm{Tl}$ ) show an upward enrichment, in line with their previously described metasomatic addition. Joining the latter element group is $\mathrm{N}$ with an upward enrichment that suggests mobilization and downward migration from overlying shales.

The trace element observations in combination with upward Fe depletion all point towards anoxic alteration and thus there remains an unsatisfactory and apparently contradictory interpretation of the paleo-redox chemistry. To explain these data, we discuss different paragenetic histories of the paleosol that range from subaerial development under an anoxic atmosphere, development under locally anoxic conditions out of direct exchange with the atmosphere, and overprinting by reducing hydrothermal fluids.

[1] Yang et al. (2002) Geochim. Cosmochim. Acta 66: 3707-3718; [2] Wille et al. (2013) Chem. Geol. 340:68-76;

[3] Teitler et al. (2015) Precam. Res. 267: 61-27 